\title{
Management of late blight of potato through chemicals
}

\author{
Pranamika Sharma ${ }^{1}$ and Dr. M.K.Saikia ${ }^{2}$ \\ Department of Plant Pathology Assam Agricultural University Jorhat, Assam, India
}

\begin{abstract}
Efforts made in the present investigation to evaluate few commonly used fungicides for their comparative efficacy against Phytophthora infestans (Mont.)de Bary- the incitant of late bight, with a view to select the most effective fungicide for the management of the disease. Among the seven fungicides, two fungicides namely Cymoxanil 8\% + Mancozeb 64\% and Dimethomorph 50\% were found most effective in pot evaluation which could reduce the disease to an extent of $99.98 \%$ and $99.95 \%$, respectively when applied before appearance of disease. The same fungicides could protect $99.84 \%$ and $99.69 \%$ of the crop when applied after $1 \%$ appearance of the disease.

The best two fungicides, Cymoxanil 8\% + Mancozeb 64\% and Dimethomorph 50\% were selected to compare their relative efficacy with the existing recommended fungicides Metalaxyl 8\% + Mancozeb 64\% and Mancozeb $75 \%$ under field condition. The highest protection (100\%) against late blight with a corresponding maximum yield (73.20 q/ha) was recorded in the treatment of one prophylactic spray with Cymoxanil 8\% + Mancozeb 64\% followed by two additional spray with same fungicide at 10 days interval. Metalaxyl 8\% + Mancozeb 64\% when applied as one prophylactic spray followed by two additional sprays at 10 days interval could protect $97.64 \%$ crop with a production of 62.60 q of healthy tuber per ha.
\end{abstract}

Key words: Potato, late blight, cymoxanil, metalaxyl resistance

\section{Introduction}

Potato (Solanum tuberosum L.) is one of the most important food and cash crop belonging to the family solanaceae. The crop has the potential to increase agricultural production in our region. In India, potato is grown in all the states producing 25 million tones from total area of 1.4 million ha. In Assam, it is grown in an area of 7.78 thousand ha producing 584 thousand ton which is very low as compared to national level.

The various factors limiting yield of potato include lack of HYV, inadequate supply of healthy seed tubers and high incidence of disease and pest. Among the diseases late blight of potato incited by Phytophthora infestans (Mont.) de Bary is the most destructive disease. In Assam the disease occurs every year in epidemic form contributing to heavy yield loss which go as high as 90\% in unsprayed crop (Bhattacharya et al.,1990).

Among the new fungicides, Cymoxanil and Dimethomorph have been evaluated as highly effective against $P$. infestans. Both the fungicides have already been used in different parts of the country for management of late blight of potato. However, it is quite essential to evaluate their efficacy against the disease under the climatic condition of Assam prior to their introduction in to the state. Therefore, an experiment has been carried out to investigate the performances of Cymoxanil and Dimethomorph under Assam condition both in pot and field conditions.

\section{Materials And Method}

The pot and field experiments were carried out in the ICR experimental farm of AAU, Jorhat during 2008 and 2009 with susceptible cv. Kufri Pukhraj. The crop was raised as per standard agronomic practices during main season (October to March).Five selected fungicides viz Moximate (Cymoxanil 8\% + Mancozeb 64\%), Lurit (Dimethomorph 50\%), Companion (Carbandazim 12\% + Mancozeb 63\%), Ridomil Gold (Mefenoxam 8\% + Mancozeb 64\%), Avtar (Hexaconazole 4\% + Zineb 68\%) along with standard fungicides Ridomil MZ 72 (Metalaxyl 8\% + Mancozeb 64\%) and Indofil M45 (Mancozeb 75\%) were evaluated under pot and field conditions. In pot experiment two potato tubers were sown in each pot with three replication/treatment and three pots were used for each replication. Forty day old plants were first sprayed with test fungicides followed by inoculation of sporangial suspension of $P$. infestans ( $4 \times 10^{4}$ sporangia/ml) after $24 \mathrm{hrs}$.of spray in another set plants were inoculated and sprayed subsequently with fungicides after $24 \mathrm{hrs}$. And disease was recorded just after 10 days of spraying.

From result of the pot experiment two best fungicides Cymoxanil 8\% + Mancozeb 64\% and Dimethomorph 50\% were selected for their field efficacy under natural condition in the next year. The experiment was laid out in Randomized Block Design with seventeen treatments with three replications with a plot size of $3 \mathrm{~m} \times 2 \mathrm{~m}$. The first spraying of fungicides was done immediately after the first appearance of a few symptoms of the disease on the leaves and was repeated thrice at an interval of ten days according to the treatment schedule. 
Percent disease severity (PDS) was recorded at 7days intervals after the last spray. The yield of potato tubers for different treatments was recorded at harvest along with the percent tuber infection. Percent disease severity (PDS) and percent tuber infection (PTS) were calculated with the help of following formulas and the values were statistically analyzed.

\section{Indentations And Equations}

$\%$ Disease Severity $(\mathrm{PDS})=\frac{\text { Area of the plant tissue affected by disease }}{\text { Total area }} \times 100$ Total area

Total no. of tuber harvest - Total no. infected tuber from the plot harvest from the plot

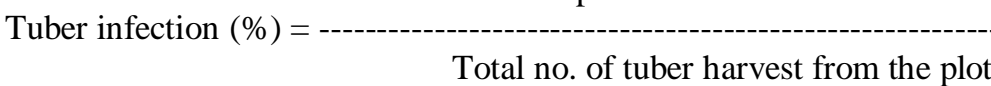
X 100

\section{Results}

\section{Pot experiment:}

In the pot experiment it was observed that all the fungicides when applied as prophylactic spray significantly reduced the foliage infection of late blight over untreated control .At 70 DAS the foliage infection due to prophylactic spray of different fungicides ranged from $0.01-99.60 \%$ where the lowest and highest foliage infection were recorded from Cymoxanil $8 \%+$ Mancozeb 64\% and untreated control (no fungicide was applied). It was also observed that all the fungicides significantly reduced the foliage infection when applied after appearance of disease. At 70 DAS the severity of late blight on foliage ranged $0.16 \%-99.68 \%$ where the minimum and maximum was recorded on Cymoxanil 8\% + Mancozeb 64\% and control treatment (table1.1), respectively.

\section{Field experiment:}

Perusal of data presented in the table 1.2 showed that the prophylactic application of either Cymoxanil $8 \%+$ Mancozeb $64 \%$ or Dimethmorph 50\% with two additional sprays of the respective fungicides at 10 days interval gave $100 \%$ control of the disease in field condition at 74DAS. Cymoxanil $8 \%+$ Mancozeb 64\% and Dimethmorph 50\% when used after appearance of the disease (curative) a very low incidence of late blight was recorded $(4.07 \%$ and $8.89 \%$, respectively) at 74 DAS with a corresponding $94.74 \%$ and $88.51 \%$ control of disease, respectively. Metalaxyl 8\% + Mancozeb 64\% or Mancozeb 75\% when applied after appearance of late blight gave $29.99 \%$ and $45.70 \%$ severity of disease (at 74 DAS), respectively with $61.24 \%$ and $40.94 \%$ control of disease.

The highest tuber yield was recorded with Cymoxanil 8\% + Mancozeb 64\% (73.20 q/ha) when used as prophylactic with two additional sprays at 10 days interval followed by Dimethomorph 50\% (72.80 q/ha).

Table1.1. Effect of fungicides on severity of late blight in pot

\begin{tabular}{|c|c|c|c|c|c|c|}
\hline \multirow[t]{3}{*}{ Treatments } & \multicolumn{3}{|c|}{ prophylactic spray } & \multicolumn{3}{|c|}{ curative spray } \\
\hline & \multicolumn{6}{|c|}{ Percent Disease Control (PDS) } \\
\hline & $50 \mathrm{DAS}$ & $60 \mathrm{DAS}$ & 70 DAS & 50 DAS & $60 \mathrm{DAS}$ & 70 DAS \\
\hline Cymoxanil $8 \%$ + Mancozeb $64 \%$ & $0.00(0.91)^{8}$ & $0.00(0.91)^{g}$ & $0.01(0.65)^{h}$ & $0.00(0.91)^{g}$ & $0.00(0.91)^{g}$ & $0.16(2.28)^{h}$ \\
\hline Dimethomorph $50 \%$ & $0.00(0.91)^{\mathrm{a}}$ & $0.00(0.91)^{g}$ & $0.04(1.15)^{g}$ & $0.00(0.91)^{g}$ & $0.00(0.91)^{g}$ & $0.31(3.20)^{g}$ \\
\hline Carbendazim $12 \%+$ Mancozeb $63 \%$ & $0.38(3.51)^{6}$ & $5.67(13.77)^{d}$ & $61.77(51.81)^{6}$ & $2.21(8.55)^{c}$ & $19.70(26.35)^{k}$ & $93.73(75.50)^{6}$ \\
\hline Mefenoxam $8 \%+$ Mancozeb $64 \%$ & $0.00(0.91)^{8}$ & $0.19(2.47)^{f}$ & $22.19(28.10)^{f}$ & $0.33(3.29)^{f}$ & $4.50(12.25)^{f}$ & $59.61(50.54)^{f}$ \\
\hline Hexaconazole $4 \%+$ Zineb $68 \%$ & $0.58(4.37)^{b}$ & $8.27(16.71)^{6}$ & $71.69(57.85)^{b}$ & $2.84(9.70)^{b}$ & $20.94(27.24)^{b}$ & $96.38(79.03)^{b}$ \\
\hline Metalaxyl $8 \%+$ Mancozeb $64 \%$ & $0.03(0.95)^{\mathrm{a}}$ & $0.46(3.90)^{8}$ & $28.07(31.99)^{8}$ & $0.57(4.32)^{\mathrm{a}}$ & $6.73(15.04)^{\mathrm{a}}$ & $69.64(56.56)^{\mathrm{s}}$ \\
\hline Mancozeb $75 \%$ & $0.18(2.43)^{d}$ & $8.79(17.25)^{b}$ & $47.96(43.83)^{d}$ & $1.09(5.99)^{d}$ & $11.59(19.90)^{d}$ & $81.28(64.36)^{d}$ \\
\hline Control & $6.18(14.40)^{2}$ & $31.73(34.28)^{2}$ & $99.60(86.39)^{2}$ & $6.18(14.40)^{2}$ & $31.74(34.29)^{2}$ & $99.68(86.85)^{2}$ \\
\hline S.Ed. \pm & 0.09 & 0.10 & 0.15 & 0.10 & 0.06 & 0.28 \\
\hline CD-5\% & 0.19 & 0.21 & 0.32 & 0.21 & 0.12 & 0.59 \\
\hline
\end{tabular}

Values in parentheses show angular transformed values

Values superscribed with same letter are not significantly different $(\mathrm{P}=0.05)$

DAS-Days After Sowing 
Table 1.2. Effect of spray of fungicides on severity of late blight, tuber infection and total tuber yield in field

\begin{tabular}{|c|c|c|c|c|c|}
\hline Treatweats & $60 \mathrm{DAS}$ & $67 \mathrm{DAS}$ & $74 D A S$ & \multirow{2}{*}{$\begin{array}{l}\text { Tuber infection } \\
\qquad(\%)^{*}\end{array}$} & \multirow{2}{*}{$\begin{array}{l}\text { Healthy tuber } \\
\text { jield }(q / h a)^{*}\end{array}$} \\
\hline & \multicolumn{3}{|c|}{ Percent Disease Control (PDS) } & & \\
\hline PS w th Cyworan $5 \%+$ Mancoceb $64 \%$ & $0.00(0.91)^{2}$ & $0.00(0.91)$ & $0.60(4.45)$ & $260^{2}(928)$ & $60.60^{2}$ \\
\hline PS w th Ketalar $18 \%$ - Macooseb $64 \%$ & $0.23(2.78)^{7}$ & $0.86(531) \beta$ & $16.83\left(2422 f^{f}\right.$ & $26.40^{2}(30.92)$ & $48.6 \mathrm{th}$ \\
\hline PS wath Manosceb $75 \%$ & $0.35(3.38)^{4}$ & $1.43(6.86)^{4}$ & $19.95(26.53)^{1}$ & $3280 \cdot(34.94)$ & $4280^{\circ}$ \\
\hline 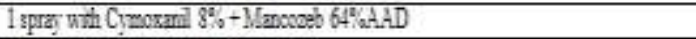 & $0.02(0.73)$ & $0.15(2.25)$ & $4.09(11.64)$ & $7203(1556)$ & $57.8 \%$ \\
\hline 1 spra wh Kanocoeb 75\%AAD & $2.6(8.29)^{2}$ & $412(1171)^{6}$ & $45.70(-2.53)^{6}$ & $43.80^{\circ}(41.44)$ & 3580 \\
\hline 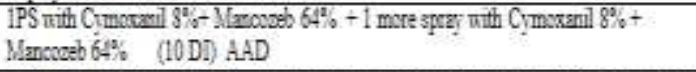 & $0.00(0.91)^{2}$ & $0.00(0.91)$ & $024(2.81)^{\approx}$ & $0.00(0.19)$ & $67 . y^{2}$ \\
\hline 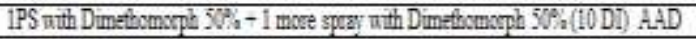 & $0.00(0.91)^{2}$ & $0.00(0.91)$ & $0.58(4.38 \%$ & $280^{2}(9.63)$ & 63.475 \\
\hline $\begin{array}{l}\text { 1PS with Wetalary } 8 \%+\text { Mancoueb } 6 \% \%+1 \text { more spray with Metalas } 8 \%- \\
\text { Mancoab 64\%(10DI) A.D }\end{array}$ & $0.07(1.46)=$ & $1.09(6.00)^{f}$ & $1205(20.31)$ & $1720^{\circ}(24.50)$ & 34.98 \\
\hline 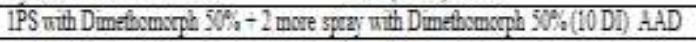 & $0.00(0.91)^{2}$ & $0.00(0.91)^{2}$ & $0.000 .91 \mathrm{~h}$ & $0.007(0.19)$ & $72.8 \%^{a}$ \\
\hline
\end{tabular}

\begin{tabular}{|c|c|c|c|c|c|}
\hline \multirow[t]{2}{*}{ Treatments } & 60DAS & 67DAS & $74 \mathrm{DAS}$ & \multirow{2}{*}{$\begin{array}{l}\text { Tuber infection } \\
\qquad(90)^{*}\end{array}$} & \multirow{2}{*}{$\begin{array}{l}\text { Healthy tuber yield } \\
\qquad(q \text { ha })^{*}\end{array}$} \\
\hline & \multicolumn{3}{|c|}{ Percent Disease Control(PDS) } & & \\
\hline $\begin{array}{l}\text { IPS nith Metaland } 8 \% \text { - Mancozeb } 64 \% \text { - I more spray nith Metalary/8\%- } \\
\text { Mancozeb } 64 \%(10 \mathrm{DD} \mathrm{ALD}\end{array}$ & $0.00(0.91)^{2}$ & $0.00(0.91 \%$ & $1.83(7.77)$ & $6.800(15.12)$ & $6260^{\circ}$ \\
\hline IPS with Mancozeb $75 \%$ - 2 more spray with Mancozeb $75 \%$ (10 DI) AAD & $0.00(0.91)^{2}$ & $0.00(0.91)$ & $4.03(11.58)^{2}$ & $10.80^{f}(19.19)$ & $5460^{\circ}$ \\
\hline Coetrol & $\begin{array}{c}6.08 \\
(1427)^{2}\end{array}$ & $\begin{array}{c}10.58 \\
(18.98)^{2}\end{array}$ & $77.38(61.60)$ & $55.002(47.87)$ & $15.40^{2}$ \\
\hline SEd $=$ & 0.05 & 0.10 & 0.09 & 0.50 & 0.34 \\
\hline CD. $5 \%$ & 0.10 & 020 & 0.19 & 2,41 & 1.66 \\
\hline
\end{tabular}

* Observations are mean of three replications

Values superscribed with same letter are not significantly different $(\mathrm{P}=0.05)$

Values in parentheses show angular values

*PS : Prophylactic spray

*AAD : After appearance of disease

\section{Discussion}

It was noticed that Cymoxanil $8 \%+$ Mancozeb $64 \%$ acted as the best fungicide when applied as prophylactic as well as curative measures. The results were in conformity with the findings of Grayson et al. (1995) that the Cymoxanil 8\%+ Mancozeb 64\% and Dimethomorph 50\% were effective oomycetes fungicide useful for the control of late blight on potatoes by preventive (prophylactic) as well as moderate curative (therapeutic) sprays. Similar results were obtained by Johnson et al (2000) who reported that Cymoxanil 8\% + Mancozeb 64\% had some activity after infection. Dimethomorph plus Mancozeb and Cymoxanil plus Mancozeb reduced sporulation more consistently (Johnson et al., 2000) to control the late blight disease compared to others. In the present investigation it was observed that the spray with Metalaxyl $8 \%+$ Mancozeb $64 \%$ was not found effective. It might be due to continuous and increased use of Metalaxyl $8 \%+$ Mancozeb $64 \%$ may lead to the development of resistant strain of P.infestans and it was supported by foregoing workers Ali and Dey (1999), Singh et al. (2005).

All the treatments showed significantly better foliage controlled as well as tuber yield over non- treated control. The results of this study were consistent with previous studies and indicated that the application of protective fungicides could reduce foliar late blight to acceptable levels (Clayton and Shattock, 1995; Fontem, 2001; Kassa and Buyene, 2001; Kirk et al., 2001; Ojiambo et al., 2001).

In the present investigation it was observed that Cymoxanil 8\%+ Mancozeb 64\% and Dimethomorph $50 \%$ gave best protection to the crop when applied after appearance of the disease compared to Metalaxyl $8 \%+$ Mancozeb 64\%. The observation made in the present investigation was conformed to the views of Johnson et al. (1997) that some fungicides, such as Dimethomorph, Cymoxanil, Propamocarb hydrochloride or Chlorothalonil had post-infection activity that inhibited sporulation and/or restricted lesion expansion. 


\section{Acknowledgements}

The authors are thankful to the professor and Head, Department of Plant Pathology, Assam Agricultural University, Jorhat, for providing all facilities and Dr.P.K.Dutta, Professor, Department of Plant Pathology, Assam Agricultural University, Jorhat, for his valuable guidance and support.

\section{References}

[1] Gupta, V.K.; Joseph, T.A. and Srivastava, A.K. (2009). Potato varieties popular in the North - eastern Region Potato in North East

[2] Bhattacharya, S.K.; Shekhawat, G.S. and Singh, B.P. (1990). Potato late blight. Tech. Bull. No. 27, C.P.R.I., Shimla, 40 PP

[3] Grayson, B.T.; Batten, D.M. and Walter, D. (1995). Adjuvant Effects on the therapeutic Control of Potato Late Blight by Dimethomorph Wettable Powder formulations. Pest Management Science 46(4): 355-359.

[4] Johnson, D.A.; Cummings, T.F. and Hamm, P.B. (2000). Cost of fungicides used to manage potato late blight in the Columbia Basin: 1996 to 1998. Plant Dis. 84: 399-402.

[5] Ali, M.S. and Dey, T.K. (1999). Management of late blight in Bangladesh. In : Late blight: A threat to global food security. Proc. of Global initiative on Late Blight Conf. March 16-19, 1999. Vol. 1.

[6] Singh, P.H.; Singh, B. P.; Singh, L. and Gupta, J. (2005). Comparative aggressiveness of Metalaxyl resistant and sensitive is olates of Phytophthora infestans. Potato J. 32 (1-2): $61-65$.

[7] Clayton R.C. and Shattock R.C. (1995). Reduced fungicide inputs to control Phytophthora infestans in potato cultivars with high levels of polygenic resistance. Potato Research 38: 399-405.

[8] Fontem, D.A. (2001). Influence of rate and frequency of Ridomil Plus applications on late blight severity and potato yields in Cameroon. African Crop Science J. 9(1): 235-243.

[9] Kassa, B. and Buyene, H. (2001). Efficacy and economics of fungicide spray in the control of late blight in Ethiopia. African Crop Science J. 9: (1): 245-250.

[10] Kirk, W.W.; Felcher, K.J.; Douches, D.S.; Coombs, J.M.; Stein, J.M.; Baker, K.M. and Hammerschmidt, R. (2001). Effect of host plant resistance and reduced rates and frequencies of fungicide application to control potato late blight. Plant Dis. 85: 1113-1118.

[11] Ojiambo, P.S.; Namanda, S.; Olanya, O.M.; El-Bedewey, R.; Hakiza, J.J.; Adipala, E. and Forbes, G. (2001). Impact of fungicide application and late blight development on potato growth parameters and yields in tropical highlands of Kenya and Uganda. African Crop Science J. 9(1): 225-233.

[12] Johnson, D.A.; Cummings, T.F.; Hamm, P.B.; Rowe, R.C.; Miller, J.S.; Thornton, R.E.; Pelter, G.Q. and Sorensen, E.J. (1997). Potato late blight in the Columbia Basin: An economic analysis of the 1995 epidemic. Plant Dis. 81: 103-106.

[13] Mayee, C.D. and Datar, V.V.(1986). Phytopathometry. Technical Bulletin 1 (Special Bulletin 3). Marathwada Agricultural University Press, Parbhani. p.218. 